\title{
Characterisation of early responses in lead accumulation and localization of Salix babylonica L. roots
}

Wenxiu Xue, Yi Jiang, Xiaoshuo Shang and Jinhua Zou* (D)

\begin{abstract}
Background: Lead $(\mathrm{Pb})$ is a harmful pollutant that disrupts normal functions from the cell to organ levels. Salix babylonica is characterized by high biomass productivity, high transpiration rates, and species specific Pb. Better understanding the accumulating and transporting $\mathrm{Pb}$ capability in shoots and roots of $\mathrm{S}$. babylonica, the toxic effects of $\mathrm{Pb}$ and the subcellular distribution of $\mathrm{Pb}$ is very important.
\end{abstract}

Results: $\mathrm{Pb}$ exerted inhibitory effects on the roots and shoots growth at all $\mathrm{Pb}$ concentrations. According to the results utilizing inductively coupled plasma atomic emission spectrometry (ICP-AES), S. babylonica can be considered as a plant with great phytoextraction potentials as translocation factor (TF) value $>1$ is observed in all treatment groups throughout the experiment. The Leadmium ${ }^{\mathrm{TM}}$ Green AM dye test results indicated that Pb ions initially entered elongation zone cells and accumulated in this area. Then, ions were gradually accumulated in the meristem zone. After $24 \mathrm{~h}$ of $\mathrm{Pb}$ exposure, $\mathrm{Pb}$ accumulated in the meristem zone. The scanning electron microscopy (SEM) and energy-dispersive X-ray analyses (EDXA) results confirmed the fluorescent probe observations and indicated that $\mathrm{Pb}$ was localized to the cell wall and cytoplasm. In transverse sections of the mature zone, $\mathrm{Pb}$ levels in the cell wall and cytoplasm of epidermal cells was the lowest compared to cortical and vessel cells, and an increasing trend in $\mathrm{Pb}$ content was detected in cortical cells from the epidermis to vascular cylinder. Similar results were shown in the Pb content in the cell wall and cytoplasm of the transverse sections of the meristem. Cell damage in the roots exposed to $\mathrm{Pb}$ was detected by propidium iodide (PI) staining, which was in agreement with the findings of $\mathrm{Pb}$ absorption in different zones of $\mathrm{S}$. babylonica roots under Pb stress.

Conclusion: S. babylonica L. is observed as a plant with great potential of Pb-accumulation and Pb-tolerance. The information obtained here of $\mathrm{Pb}$ accumulation and localization in S. babylonica roots can furthers our understanding of $\mathrm{Pb}$-induced toxicity and its tolerance mechanisms, which will provide valuable and scientific information to phytoremediation investigations of other woody plants under Pb stress.

Keywords: Energy-dispersive X-ray analyses (EDXA), Fluorescence labeling, Lead (Pb), Propidium iodide (PI), Salix babylonica L., Subcellular localization

\footnotetext{
* Correspondence: zjhmon@126.com

Tianjin Key Laboratory of Animal and Plant Resistance, College of Life

Science, Tianjin Normal University, Tianjin 300387, China
}

C C The Author(s). 2020 Open Access This article is licensed under a Creative Commons Attribution 4.0 International License, which permits use, sharing, adaptation, distribution and reproduction in any medium or format, as long as you give appropriate credit to the original author(s) and the source, provide a link to the Creative Commons licence, and indicate if changes were made. The images or other third party material in this article are included in the article's Creative Commons licence, unless indicated otherwise in a credit line to the material. If material is not included in the article's Creative Commons licence and your intended use is not permitted by statutory regulation or exceeds the permitted use, you will need to obtain permission directly from the copyright holder. To view a copy of this licence, visit http://creativecommons.org/licenses/by/4.0/. The Creative Commons Public Domain Dedication waiver (http://creativecommons.org/publicdomain/zero/1.0/) applies to the data made available in this article, unless otherwise stated in a credit line to the data. 


\section{Background}

Nowadays, the rapid growth of industrialization and human activities, such as mining and smelting of lead $(\mathrm{Pb})$ ores, can result in environmental $\mathrm{Pb}$ pollution and its entering into the food chain, which poses a great risk to the health of both plants and human beings $[1,2]$. Therefore, $\mathrm{Pb}$ pollution has been becoming a critical social problem today [3]. Among all the heavy metals, $\mathrm{Pb}$ toxicity is only lower than As [4]. It is not only nonessential for plant growth, but often toxic to plant metabolism. $\mathrm{Pb}$ disrupts normal functions from the cell to organ levels, such as $\mathrm{Pb}$ inducing damage of root tip meristematic cells and guard cells in leaves and disturbing the function of chloroplast, mitochondria, nucleolus and vacuole [5-8]. Evidence has demonstrated that $\mathrm{Pb}$ can be easily absorbed, transformed, and accumulated in plant tissues, in which the roots are the primary sites of accumulation [9-12]. A higher percentage of accumulated $\mathrm{Pb}$ is restricted within the roots, while only a small fraction of it is transported to the aerial parts of plants $[13,14]$. Previous reports demonstrated that $\mathrm{Pb}$ toxicity is associated with the inducement of a low mitotic index, disturbance of mitosis, visible chloroplast alterations, plant cell malformations, mitochondrial system abnormalities, inward invagination of cell walls, plasma membrane distortions, oversized vacuoles, and irregular plastoglobuli formations [15-21].

The Salicaceae family contains the Salix (willows) and Populus (poplars) genera, which are comprised of several woody species and hybrids. Many of them have accommodated to certain ecological niches, for example the places that are nutrient-poor, dry, wet or contaminated by metal $[22,23]$. Willows with the characteristics of high biomass, accumulating and translocating heavy metals to shoots easily are considered as excellent phytoremediation species [24-27]. S. babylonica is a willow species that grows in a wide range of climatic conditions and is one of the most widely cultivated willow species in China [28]. This species is preferred for the phytoremediation of trace metal-contaminated land due to its easy propagation and cultivation, fast growth, large biomass, and deep root system [23, 28]. An early study reported that $S$. babylonica tolerates and accumulates $\mathrm{Pb}$, suggesting that it has considerable potential for remediating $\mathrm{Pb}$ pollution [29]. However, little is known in this respect.

Phytoremediation is an economic way which utilize the potential of plants to transform or eliminate the environmental contaminants by accumulating in their tissues, which is a cheap alternative that complements common, conventional methods [30,31]. The success of phytoextraction is mainly determined by the identification of native high biomass yielding, the capability of the plants for the heavy metal accumulation and translocation, the tolerance to high heavy metal concentrations [32]. Better understanding the uptake, accumulation, transportation and distribution of heavy metals in plants and the toxic effects on tissues, organs and cells are needed and very important.

In the present investigation, the early responses of $S$. babylonica roots exposed to different $\mathrm{Pb}$ concentrations in respect to $\mathrm{Pb}$ uptake and accumulation, subcellular distribution, and the toxic effects of $\mathrm{Pb}$ on plant growth and cell damage were studied by utilizing inductively coupled plasma atomic emission spectrometry (ICPAES), fluorescence labeling, propidium iodide (PI) staining, scanning electron microscopy (SEM), and energydispersive X-ray analyses (EDXA). The data will be very valuable in better our understanding of $\mathrm{Pb}$-induced toxicity and the associated tolerance mechanisms in woody plants under $\mathrm{Pb}$ stress.

\section{Results}

\section{Effects of $\mathrm{Pb}$ on seedling growth}

The $\mathrm{Pb}$ effects on $\mathrm{S}$. babylonica root growth varied with different $\mathrm{Pb}$ concentrations after $7 \mathrm{~d}$ (Fig. 1). Compared to the control, $\mathrm{Pb}$ exerted significant inhibitory effects on roots and shoots $(p<0.05)$. The data also revealed that both root and shoot length decreased significantly $(p<0.05)$ as $\mathrm{Pb}$ concentrations increased.

\section{$\mathrm{Pb}$ accumulation}

The ICP-AES data showed that the Pb levels in S. babylonica roots exposed to $\mathrm{Pb}$ solution for $7 \mathrm{~d}$ increased significantly $(p<0.05)$ when compared to the control and exhibited a gradually increasing trend as $\mathrm{Pb}$ concentrations increased (1, 10, 50 and $100 \mu \mathrm{mol} / \mathrm{L}$ ) (Table 1). The $\mathrm{Pb}$ content in the stems and leaves exhibited the same trend as the roots. $\mathrm{Pb}$ accumulation in shoots was higher than that in the roots. At $100 \mu \mathrm{mol} / \mathrm{L} \mathrm{Pb}$ treatment for $7 \mathrm{~d}$, the root $\mathrm{Pb}$ accumulation was $78.78 \pm$ $0.34 \mu \mathrm{g} / \mathrm{g}$ dry weight of the tissue, and the shoot $\mathrm{Pb}$ accumulation was $151.37 \pm 0.16 \mu \mathrm{g} / \mathrm{g}$ dry weight of the tissue.

Translocation factors (TF) of all treatments were also calculated, the data also confirmed the $\mathrm{Pb}$ accumulation in S. babylonica shoots and roots under $\mathrm{Pb}$ stress. The highest TF was found at 1 and $10 \mu \mathrm{mol} / \mathrm{L} \mathrm{Pb}$ treatment, and there was a decreasing trend in the TF values as $\mathrm{Pb}$ concentrations increased (Table 1). However, the TF value $>1$ was observed in all treatment groups throughout the experiment (Table 1).

\section{Effects of $\mathrm{Pb}$ on cell damage}

In order to investigate the toxic effects of $\mathrm{Pb}$ on cell damage in root tips, PI dyes were used to visualize dead cells at longitudinal sections of $S$. babylonica root tips exposed to $0,1,10,50$, or $100 \mu \mathrm{mol} / \mathrm{L} \mathrm{Pb}$ for $3,6,12$, 


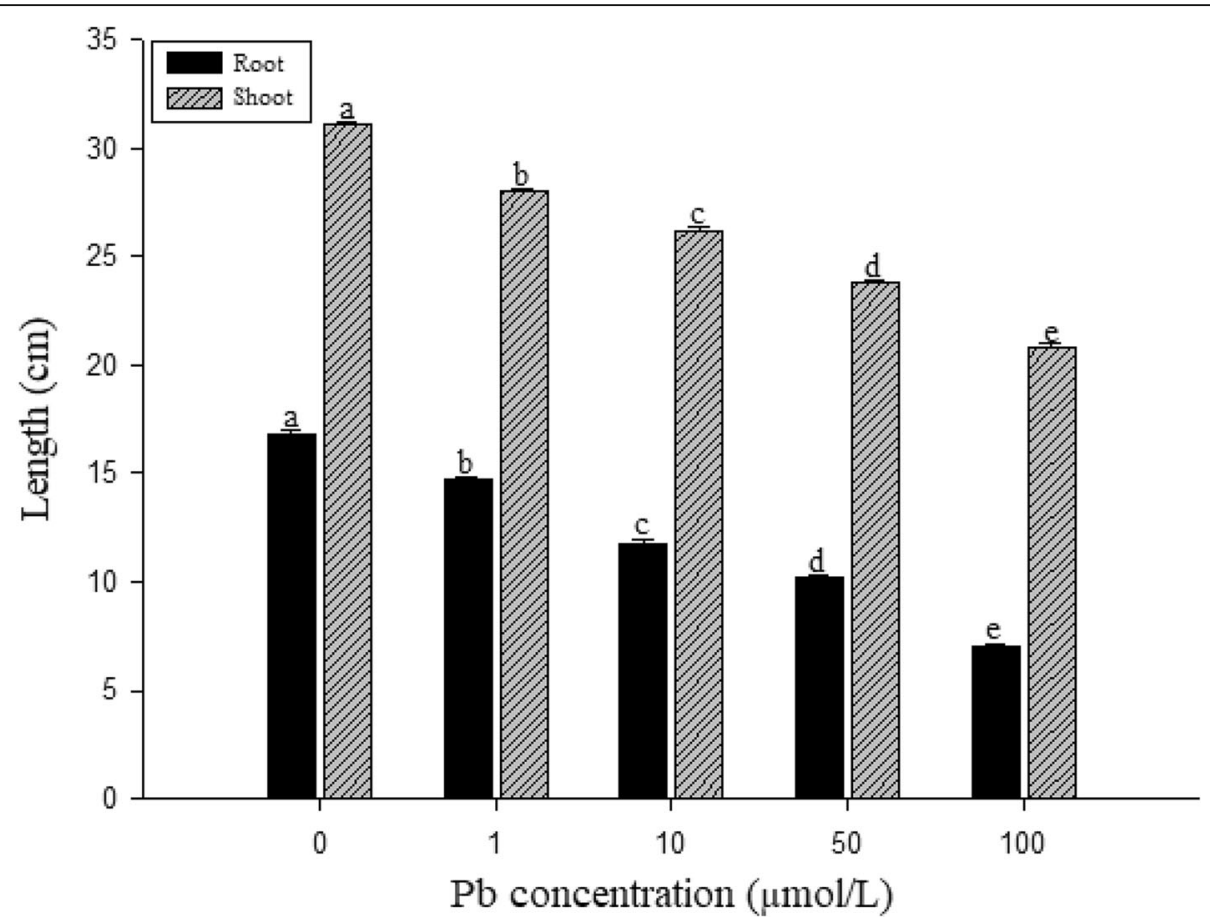

Fig. 1 Effects of Pb on S. babylonica root and shoot length exposed to 0, 1, 10, 50, or $100 \mu \mathrm{mol} / \mathrm{L} \mathrm{Pb}$ for $7 \mathrm{~d}$. Vertical bars denote the SE. Different letters indicate significant differences $(n=10, p<0.05)$

and $24 \mathrm{~h}$ (Fig. 2a-d). Red fluorescence is an indicator of cell damage. In the root tips of S. babylonica, the different $\mathrm{Pb}$ concentrations at different treatment time were responsible for the degree of cell damage caused by $\mathrm{Pb}$ (Fig. 2a-d). A significant red fluorescence signal was not observed in the control roots (Fig. 2A1-D1). Weak red fluorescence labeling gradually appeared in root tip cells exposed to 1 or $10 \mu \mathrm{mol} / \mathrm{L} \mathrm{Pb}$ for $12 \mathrm{~h}$ (Fig. 2C2, C3), $50 \mu \mathrm{mol} / \mathrm{L} \mathrm{Pb}$ for $6 \mathrm{~h}$ (Fig. 2B4), and $100 \mu \mathrm{mol} / \mathrm{L} \mathrm{Pb}$ for $3 \mathrm{~h}$ (Fig. 2A5), indicating that $\mathrm{Pb}$ could induce cell damage as soon as $3 \mathrm{~h}$ after $\mathrm{Pb}$ exposure. Fluorescence intensity was more pronounced as $\mathrm{Pb}$ concentrations increased and due to prolonged exposure. The strongest fluorescence was observed in root tip cells treated with $100 \mu \mathrm{mol} / \mathrm{L} \mathrm{Pb}$. Data from the fluorescence density

Table $1 \mathrm{~Pb}$ levels of different S. babylonica organs exposed to different $\mathrm{Pb}$ concentrations for $7 \mathrm{~d}$

\begin{tabular}{lllll}
\hline $\begin{array}{l}\text { Treatment } \\
(\mu \mathrm{mol} / \mathrm{L})\end{array}$ & \multicolumn{2}{l}{ Dry weight $(\mu \mathrm{g} / \mathrm{g}) \pm \mathrm{SE}$} & TF \\
\cline { 2 - 4 } & Stem & Leaf & Root & \\
\hline 0 & $9.91 \pm 0.04 \mathrm{a}$ & $8.50 \pm 0.43 \mathrm{a}$ & $11.50 \pm 0.27 \mathrm{a}$ & 1.60 \\
1 & $41.50 \pm 0.50 \mathrm{~b}$ & $33.51 \pm 0.91 \mathrm{~b}$ & $31.56 \pm 0.65 \mathrm{~b}$ & 2.38 \\
10 & $70.85 \pm 0.06 \mathrm{c}$ & $45.79 \pm 0.01 \mathrm{c}$ & $48.91 \pm 0.05 \mathrm{c}$ & 2.38 \\
50 & $83.08 \pm 0.17 \mathrm{~d}$ & $49.48 \pm 0.09 \mathrm{~d}$ & $59.43 \pm 0.04 \mathrm{~d}$ & 2.23 \\
100 & $98.38 \pm 0.13 \mathrm{e}$ & $52.99 \pm 0.03 \mathrm{e}$ & $78.78 \pm 0.34 \mathrm{e}$ & 1.92 \\
\hline
\end{tabular}

Different letters indicate significant differences $(p<0.05)$. Data are presented as mean $\pm \operatorname{SE}(n=5)$ analysis confirmed these findings (Fig. 3). Cell damage increased significantly as $\mathrm{Pb}$ concentrations and treatment time increased $(p<0.05)$. In $S$. babylonica root tips, the $\mathrm{Pb}$ accumulation and location and the distribution of cell death are almost the same. The results showed the distribution of cell damage in various root areas after $S$. babylonica was stressed by $100 \mu \mathrm{mol} / \mathrm{L} \mathrm{Pb}$ for 3, 6, 12 and $24 \mathrm{~h}$ (Fig. 4). When compared with meristem and mature zones, the degree of necrotic cells in the elongation zone was greatly higher after $3-12 \mathrm{~h}$ of $\mathrm{Pb}$ exposure $(p<0.05)$. After exposure to $100 \mu \mathrm{mol} / \mathrm{L} \mathrm{Pb}$ for $24 \mathrm{~h}$, the level of necrotic cells in the meristem zone was significantly higher $(p<0.05)$ compared to the elongation and mature zones.

Cell damage was observed in transverse sections of the mature zone of $S$. babylonica roots exposed to $0,1,10$, 50 , or $100 \mu \mathrm{mol} / \mathrm{L} \mathrm{Pb}$ for $24 \mathrm{~h}$ (Fig. 5a-e). In control root tip cells, there was very weak red fluorescence been observed, indicating a little cell damage in the normal plant growth (Fig. 5a). After $24 \mathrm{~h}$ in $1 \mu \mathrm{mol} / \mathrm{L} \mathrm{Pb}$ treatment, compared to the control, stronger red fluorescence was detected suggesting more dead cells were induced by $\mathrm{Pb}$ in $S$. babylonica roots (Fig. 5b). This toxic effect increased as $\mathrm{Pb}$ concentrations increased (Fig. 5c-e). At low $\mathrm{Pb}$ concentrations $(1 \mu \mathrm{mol} / \mathrm{L})$, low levels of fluorescence intensity were mainly concentrated in epidermal and cortical cells near the epidermis (Fig. 5b). As Pb concentrations increased, strong red fluorescence was 


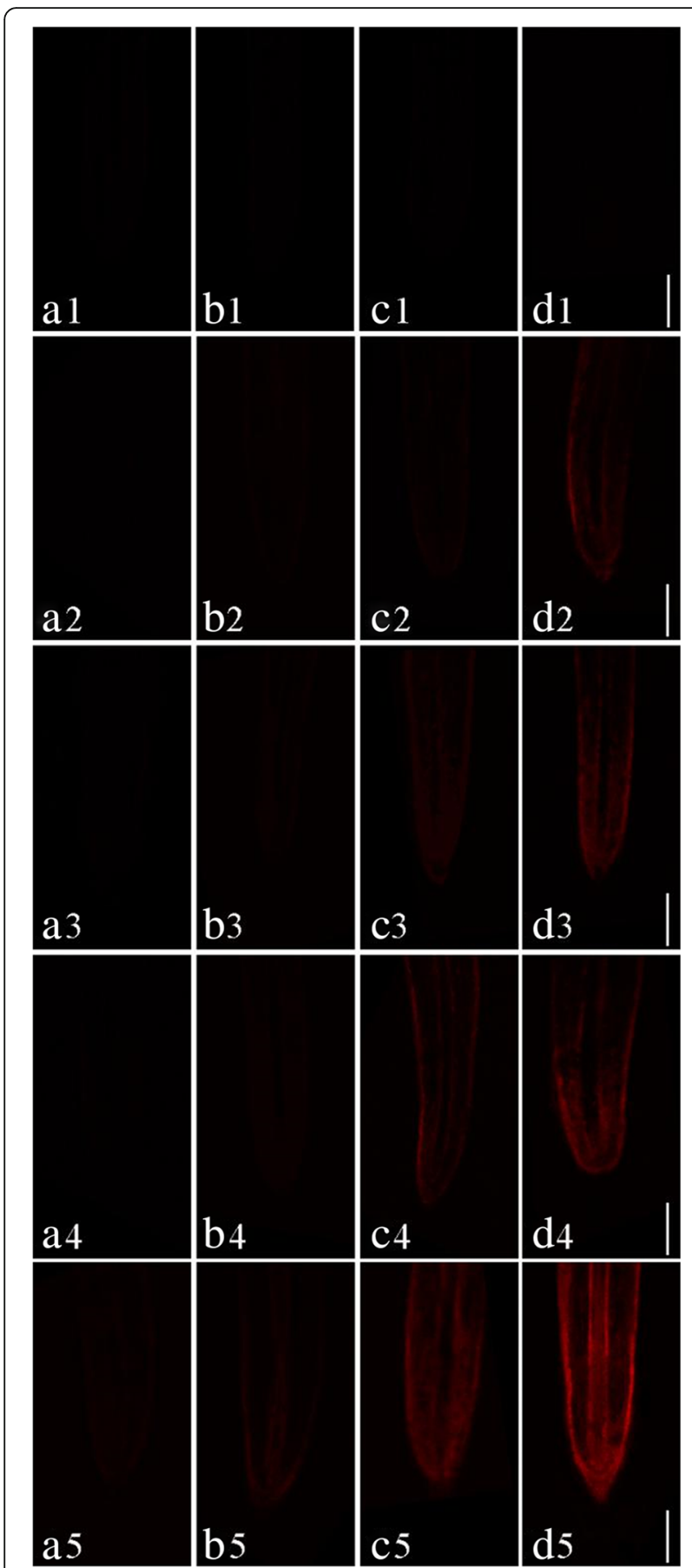

Fig. 2 Micrographs of S. babylonica roots using PI dye at longitudinal root tips exposed to different $\mathrm{Pb}$ concentrations $(0,1$, $10,50$, or $100 \mu \mathrm{mol} / \mathrm{L})$ for different treatment times $(0,3,6,12$, and 24 h). A1-D1: Control without Pb for 3, 6, 12, and 24 h; A2-D2: $1 \mu \mathrm{mol} / \mathrm{L} \mathrm{Pb}$ for 3, 6, 12, and $24 \mathrm{~h}$; A3-D3: $10 \mu \mathrm{mol} / \mathrm{L} \mathrm{Pb}$ for 3, 6, 12, and $24 \mathrm{~h}$; A4-D4: 50 mol/L Pb for 3, 6, 12, and $24 \mathrm{~h}$; A5-D5: $100 \mu \mathrm{mol} / \mathrm{L} \mathrm{Pb}$ for $3,6,12$, and $24 \mathrm{~h}$. Scale bar $=1 \mathrm{~mm}$ observed. The toxic effects of $\mathrm{Pb}$ on cell damage were observed in cortical cells near the vascular column of roots exposed to $10 \mu \mathrm{mol} / \mathrm{L} \mathrm{Pb}$ (Fig. 5C). Increasing fluorescence intensity appeared in all root cortical cells treated with 50 or $100 \mu \mathrm{mol} / \mathrm{L} \mathrm{Pb}$ (Fig. 5d, e). The fluorescence density analysis revealed significant $\mathrm{Pb}$-induced cell damage at transverse sections of $S$. babylonica roots under $\mathrm{Pb}$ stress $(p<0.05)$; this toxic effect increased as $\mathrm{Pb}$ concentrations increased (Fig. 6).

\section{$\mathrm{Pb}$ distribution in root tips}

The $\mathrm{Pb}$ distribution in S. babylonica root tips exposed to $0,1,10,50$, or $100 \mu \mathrm{mol} / \mathrm{L} \mathrm{Pb}$ for $3,6,12$, and $24 \mathrm{~h}$ was conducted using a Pb-specific Leadmium Green AM dye probe. The fluorescent dye revealed a bright and clear green fluorescence in root tip cells of $\mathrm{Pb}$-treated roots due to the $\mathrm{Pb}$ specific probe Leadmium ${ }^{\mathrm{Tm}}$ Green AM solution (Fig. 7a-d). A significant green fluorescence signal was not detected in control root tips (Fig. 7A1-D1). A weak green fluorescence signal appeared first in the root tip cells exposed to 10,50 , or $100 \mu \mathrm{mol} / \mathrm{L} \mathrm{Pb}$ for $3 \mathrm{~h}$ (Fig. 7A3-A5) compared to the control. This phenomenon was also observed in roots exposed to $1 \mu \mathrm{mol} / \mathrm{L} \mathrm{Pb}$ for $6 \mathrm{~h}$ (Fig. 7B2). These data revealed that $\mathrm{Pb}$ could enter root cells after $3 \mathrm{~h}$. The labeling of root tip cells increased as $\mathrm{Pb}$ concentrations increased and due to prolonged exposure. The strongest fluorescence in root tip cells was observed in $100 \mu \mathrm{mol} / \mathrm{L} \mathrm{Pb}$ (Fig 7A5-D5). The fluorescence density analysis confirmed the above observations (Fig. 8). The $\mathrm{Pb}$ distribution in the 3 zones of $S$. babylonica roots treated with $100 \mu \mathrm{mol} / \mathrm{L} \mathrm{Pb}$ for $3,6,12$, and $24 \mathrm{~h}$ was analyzed by Image J (Fig. 9). The Pb levels in the 3 zones of roots exposed to $\mathrm{Pb}$ for $12 \mathrm{~h}$ were significantly different $(p<$ $0.05)$ and ordered as follows: elongation zone $>$ meristem zone $>$ mature zone. The order of $\mathrm{Pb}$ contents after $24 \mathrm{~h}$ exposure was as follows: meristem area $>$ elongation area $>$ mature area. The above results showed that $\mathrm{Pb}$ absorbed and accumulated mainly in the meristem and elongation zones. These results exhibited the same trend in root cells damaged by $\mathrm{Pb}$ (Fig. 4).

\section{Subcellular localization of $\mathrm{Pb}$}

The SEM and EXDA results revealed the cellular localization of $\mathrm{Pb}$ in $S$. babylonica root tip cells exposed to $50 \mu \mathrm{mol} / \mathrm{L} \mathrm{Pb}$ for $24 \mathrm{~h}$, as well as the wt\% of $\mathrm{Pb}$ localization in specific sites. At longitudinal sections, $\mathrm{Pb}$ ions were observed in the meristem, elongation, and mature zones of $S$. babylonica root caps exposed to $\mathrm{Pb} . \mathrm{Pb}$ levels were ordered as follows: meristem zone (2.38 wt $\%)>$ elongation zone $(1.37 \mathrm{wt} \%)>$ mature zone $(1.10$ $w t \%)>$ root cap (1.05 wt\%) (Fig. 10). These findings exhibited the same trend as the $\mathrm{Pb}$-specific Leadmium Green AM dye probe observations. In transverse 


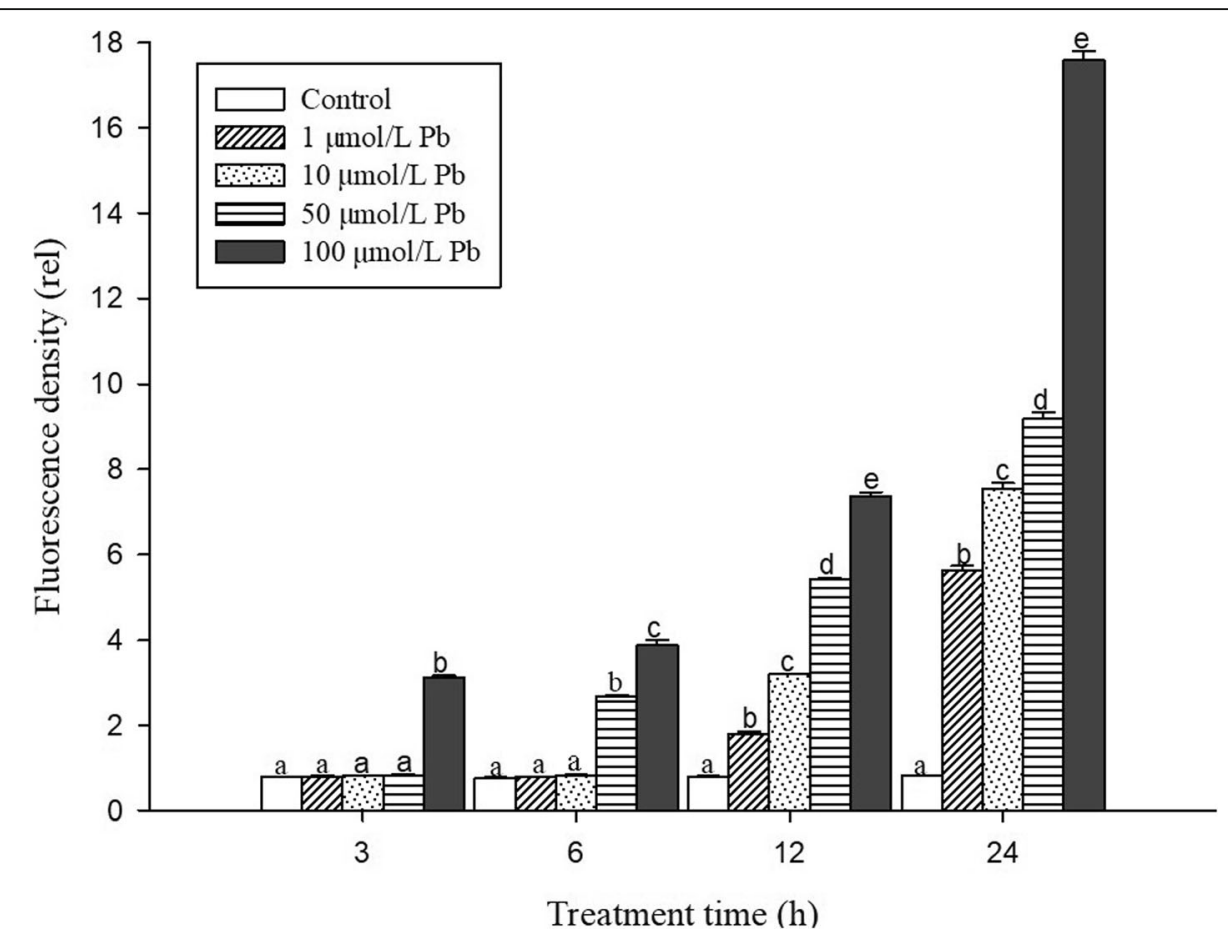

Fig. 3 Analysis of PI fluorescence density detected by Image J at longitudinal sections of roots exposed to 1, 10, 50, or 100 $\mu \mathrm{mol} / \mathrm{L}$ Pb for 3, 6, 12, and $24 \mathrm{~h}$. Vertical bars denote the SE. Different letters indicate significant differences $(p<0.05)$

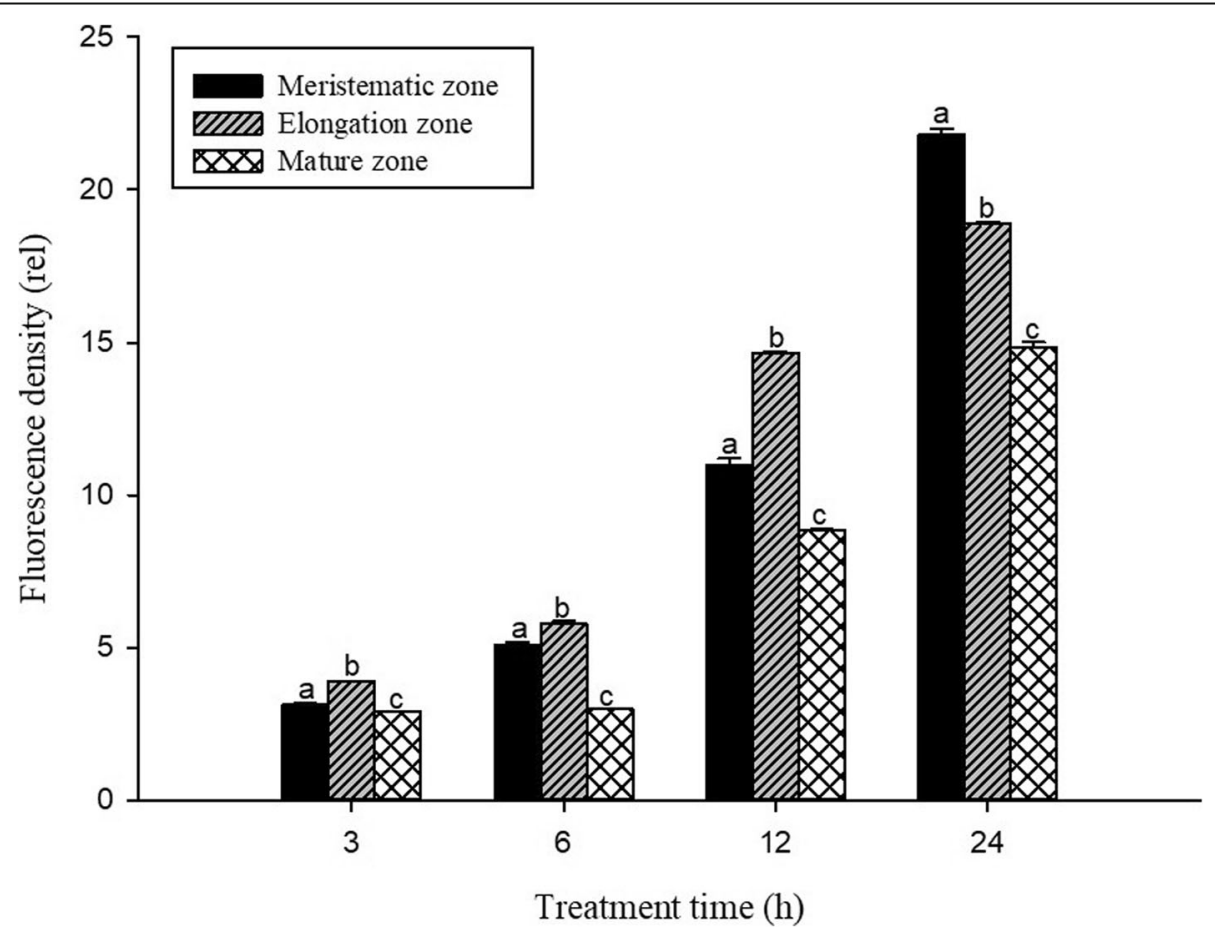

Fig. 4 Distribution of PI fluorescence density detected by Image J in different zones of S. babylonica roots treated with $100 \mu \mathrm{mol} / \mathrm{L}$ Pb for 3, 6, 12, and $24 \mathrm{~h}$. Vertical bars denote the SE. Different letters indicate significant differences $(p<0.05)$ 


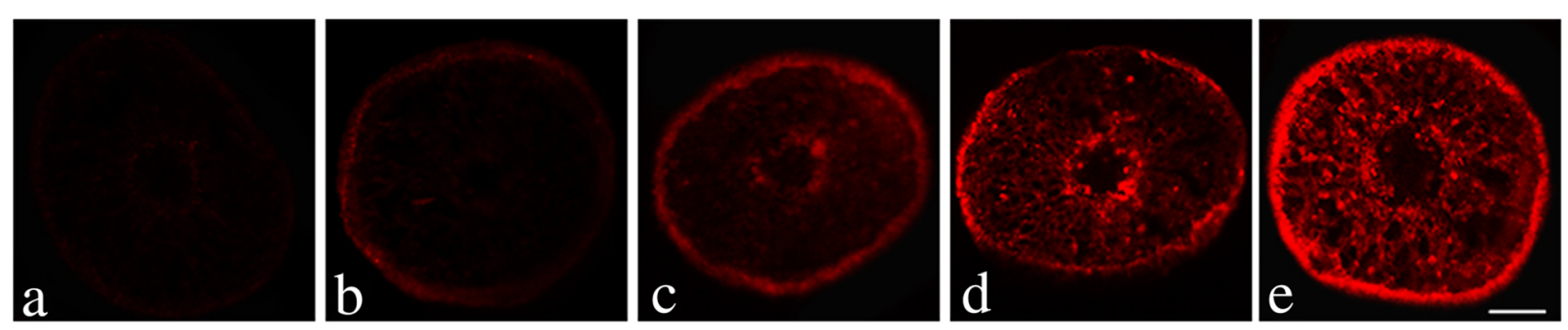

Fig. 5 Micrographs of $\mathrm{S}$. babylonica roots using $\mathrm{Pl}$ dye at transverse sections of root mature zone exposed to different $\mathrm{Pb}$ concentrations $(0,1,10$, 50, or $100 \mu \mathrm{mol} / \mathrm{L}$ ) for $24 \mathrm{~h}$. Scale bar $=200 \mu \mathrm{m}$. a: Control; b: $1 \mu \mathrm{mol} / \mathrm{L} \mathrm{Pb} ; \mathbf{c}: 10 \mu \mathrm{mol} / \mathrm{L} \mathrm{Pb;} \mathrm{d:} 50 \mu \mathrm{mol} / \mathrm{L} \mathrm{Pb}$; e: $100 \mu \mathrm{mol} / \mathrm{L} \mathrm{Pb}$

sections of the mature zone, the epidermis, cortex, and vascular cylinder were easily distinguishable (Fig. 11a). The EDXA spectra revealed that $\mathrm{Pb}$ was located in the epidermis, cortex, and vascular cylinder after Pb stress. $\mathrm{Pb}$ distribution in these tissue cells was detected in both the cytoplasm and cell wall. Pb levels in the cell wall and cytoplasm of epidermal cells was the lowest compared to cortical and vessel cells. Pb content was ordered as follows: epidermal cells $<$ cortical cells $<$ vessel cells (Fig. 11b-f). Notably, an increasing trend in $\mathrm{Pb}$ content was detected in cortical cells from the epidermis to vascular cylinder (Fig. 11c-e). Pb levels were ordered as follows: cortical cells near vascular bundle > cortical cells between the epidermis and vascular cylinder $>$ cortical cells near the epidermis (Fig. 11c-e). Pb levels in the protoderm, ground meristem and procambium of the transverse section of meristem were almost the same as those of the apical meristem (Fig. 12a). The Pb content in the cell wall and cytoplasm was ordered as follows: procambium $>$ ground meristem $>$ protoderm (Fig. 12b-f). The $\mathrm{Pb}$ content in the cell wall and cytoplasm of ground meristem gradually increased from the protoderm to procambium (Fig. 12c-e). Pb levels were ordered as follows: ground meristem cells near the protoderm $<$ ground meristem cells from the protoderm to procambium $<$ ground meristem cells near the procambium. These results demonstrated that the cell wall was the main $\mathrm{Pb}$ storage site in the ground meristem and protoderm. Moreover, the $\mathrm{Pb}$ levels in the procambium cytoplasm were higher compared to the ground meristem and protoderm. Based on

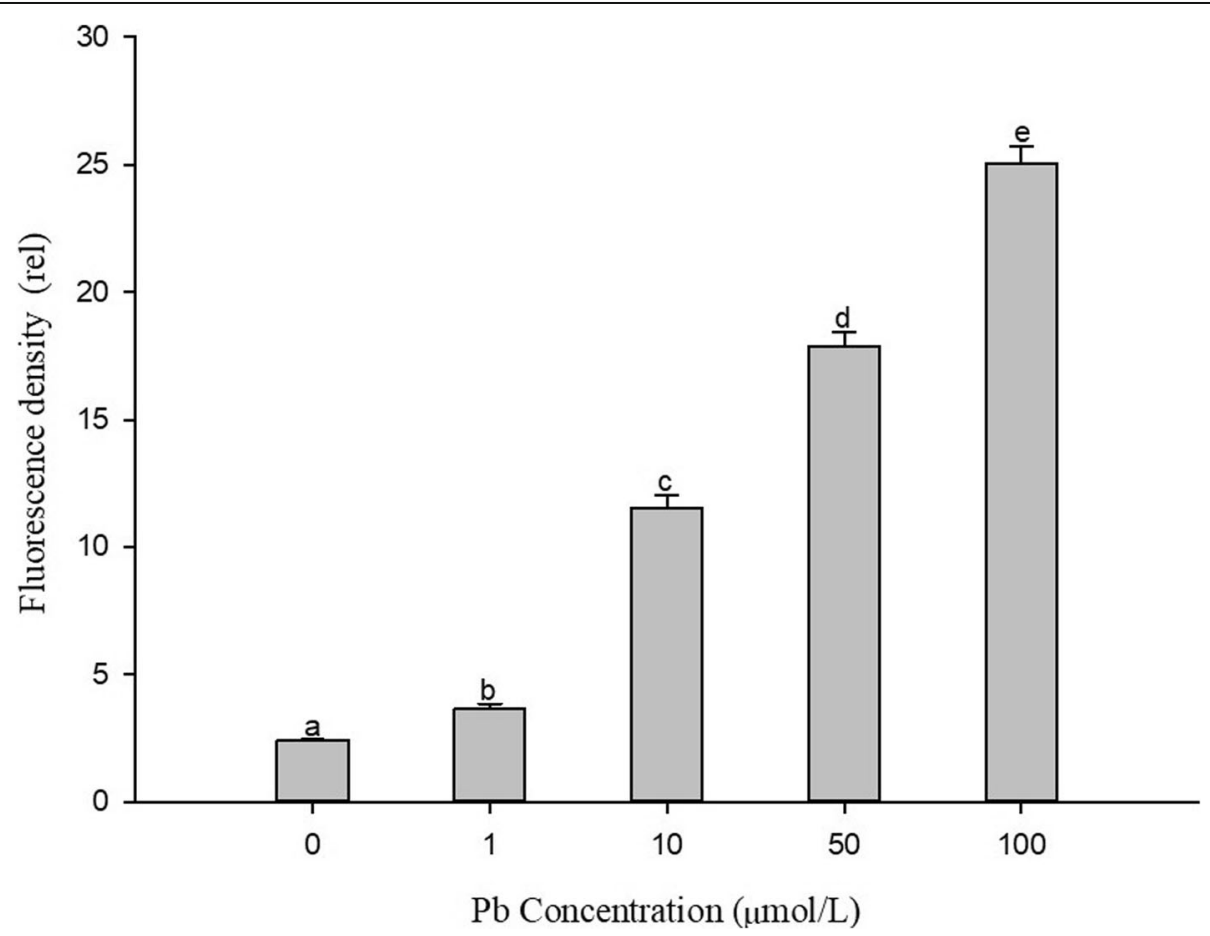

Fig. 6 Analysis of PI fluorescence density at transverse sections of root mature zone exposed to 1, 10, 50, or $100 \mu \mathrm{mol} / \mathrm{L} \mathrm{Pb}$ for $24 \mathrm{~h}$. Vertical bars denote the SE. Different letters indicate significant differences $(p<0.05)$ 


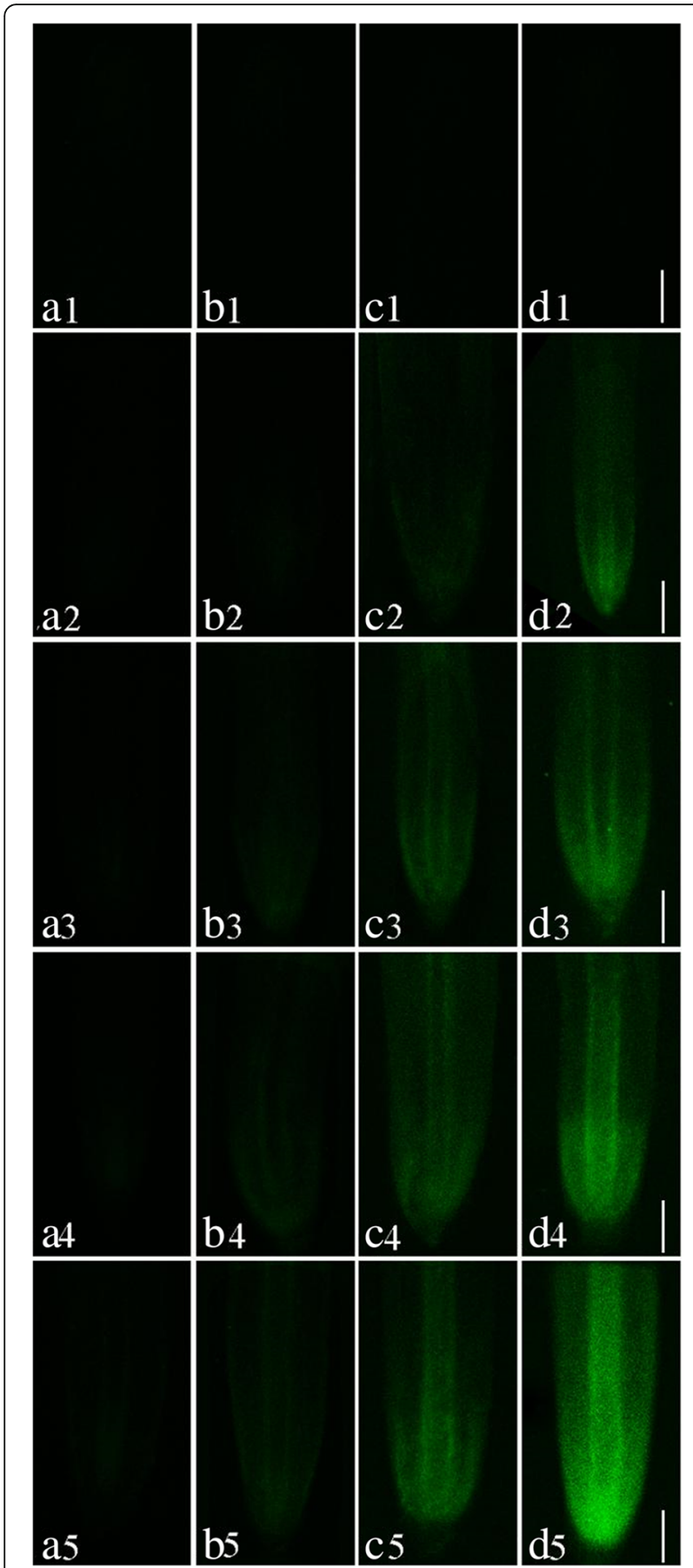

Fig. 7 Micrographs of S. babylonica roots using Leadmium Green AM dye at longitudinal sections of roots exposed to different $\mathrm{Pb}$ concentrations $(0,1,10,50$, or $100 \mu \mathrm{mol} / \mathrm{L})$ for different treatment times (3, 6, 12, and $24 \mathrm{~h})$. a1-d1: Control without Pb for 3, 6, 12, and 24 h; a2-d2: $1 \mu \mathrm{mol} / \mathrm{L} \mathrm{Pb}$ for 3, 6, 12, and 24 h; a3-d3: $10 \mu \mathrm{mol} / \mathrm{L} \mathrm{Pb}$ for 3, 6, 12, and $24 \mathrm{~h}$; a4-d4: 50 mol/L Pb for 3, 6, 12, and $24 \mathrm{~h}$; a5d5: $100 \mu \mathrm{mol} / \mathrm{L} \mathrm{Pb}$ for 3, 6, 12, and $24 \mathrm{~h}$. Scale bar $=1 \mathrm{~mm}$ the transverse sections, the $\mathrm{Pb}$ levels in mature zones were lower compared to the meristem zone.

\section{Discussion}

According to Buscaroli [33], the transport of $\mathrm{Pb}$ from the roots to shoots is a critical step in $\mathrm{Pb}$ phytoextraction. The most recognized standard criteria are based on BCF (Bio-concentration factor) or TF as an indication of phytoremediation potential for different plant species. The plants exhibiting BCF or TF values $\geq 1$ are considered as hyperaccumulators which are potential candidates for phytoextraction, and plants with the values $<1$ are constituted metal excluders which are not suitable for phytoextraction $[11,33]$. Notably, the TF value $>1$ of $\mathrm{Pb}$ from $S$. babylonica roots to shoots is observed in all treatment groups throughout the experiment, so $S$. babylonica can be considered as a plant with great phytoextraction potentials. The data here show that S. babylonica has the ability to uptake and accumulate $\mathrm{Pb}$. TF value $>1$, that is to say, large amounts of $\mathrm{Pb}$ are transported to the shoots from the roots, which differs from other plants, including Allium sativum, Ricinus communis, Brassica juncea, Neyraudia reynaudiana, and some other willow clones, in which, large amounts of $\mathrm{Pb}$ ions are accumulated in the roots and small amounts are transported to the shoots after $\mathrm{Pb}$ stress [13, 14, 25, 34, 35]. Nevertheless, some studies have reported on the use of crop plants and forest plants, including poplar and willows, to remove heavy metals from contaminated soils [22, 23, 26, 36-40]. Other investigations indicated that hyperaccumulators, plants that accumulate heavy metals from the soil into their shoots, are immensely useful in phytoextraction $[23,36]$. In this study, S. babylonica is used to evaluate its capability for TF $>1$, demonstrating that $S$. babylonica is considered as a plant with great potential of $\mathrm{Pb}$-accumulation. These results are in accordance with the findings of Chandrasekhar and Ray [11]. $\mathrm{Pb}$ accumulation in S. babylonica here is much lower than the three plants (Eclipta prostrata (L.) L., Scoparia dulcis L. and Phyllanthus niruri L.) reported by Chandrasekhar and Ray [41], which maybe due to the different $\mathrm{Pb}$ treatment method, $\mathrm{Pb}$ concentration and treatment time. Wang et al. [42] indicated that the transport from underground to above ground could be explained by the plants can preadapt and improve their tolerance to heavy metals through accumulating heavy metals in initial cuttings before rooted. Besides, more investigations are needed to carry out for further confirming the ability of S. babylonica in phytoremediation of metal contamination.

Roots contact lead and other heavy metals directly in soil system, which are sensitive to environmental stress. Root apical meristem is crucial in immediate stress response through the activation of signal cascades in other plant organs [15]. Excessive $\mathrm{Pb}$ often results in environmental contamination and inhibited plant growth. 


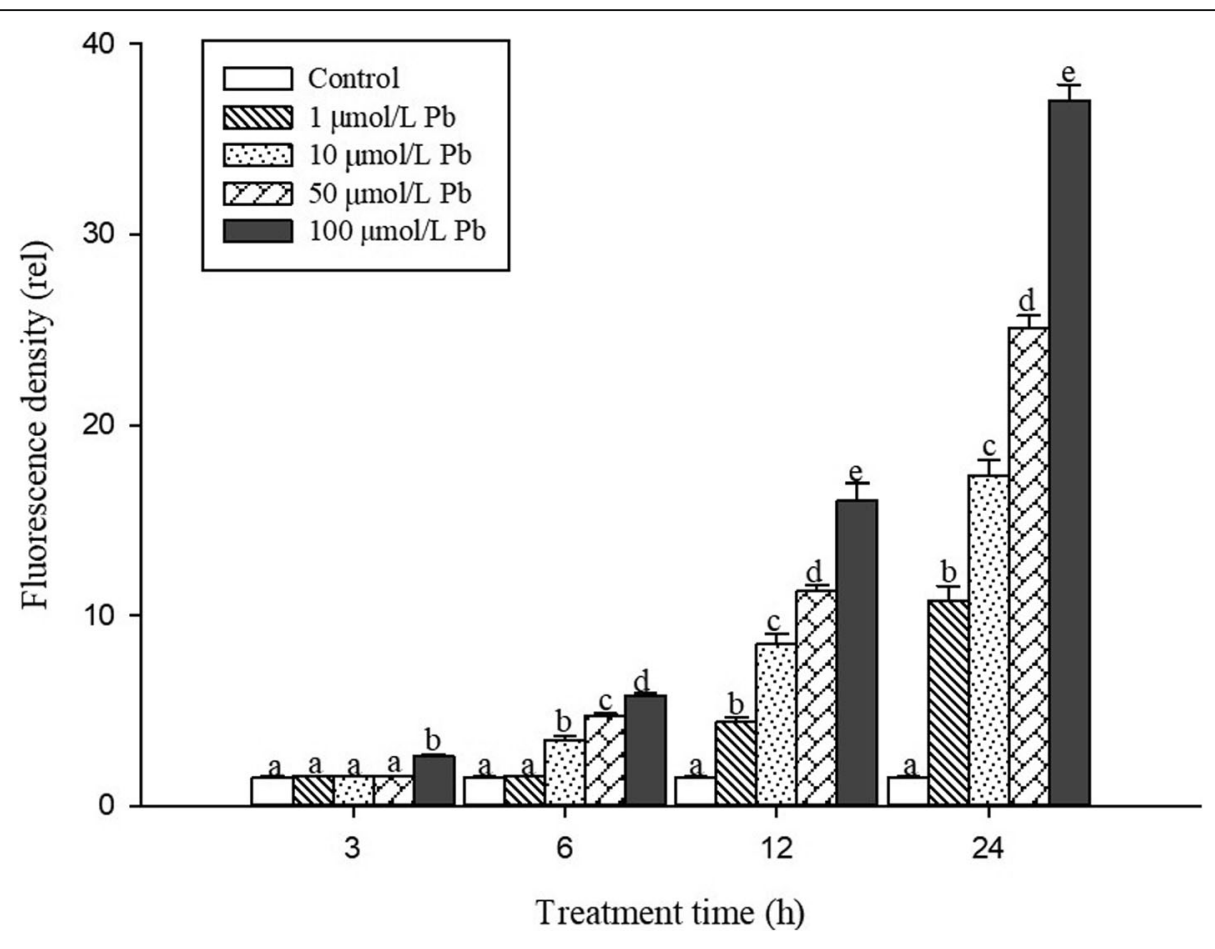

Fig. 8 Analysis of Leadamium ${ }^{\mathrm{TM}}$ Green AM dye fluorescence density detected by Image J at longitudinal sections of roots pretreated with 0, 1, 10, 50, or $100 \mu \mathrm{mol} / \mathrm{L} \mathrm{Pb}$ for 3, 6, 12, and $24 \mathrm{~h}$. Vertical bars denote the SE. Different letters indicate significant differences $(p<0.05)$

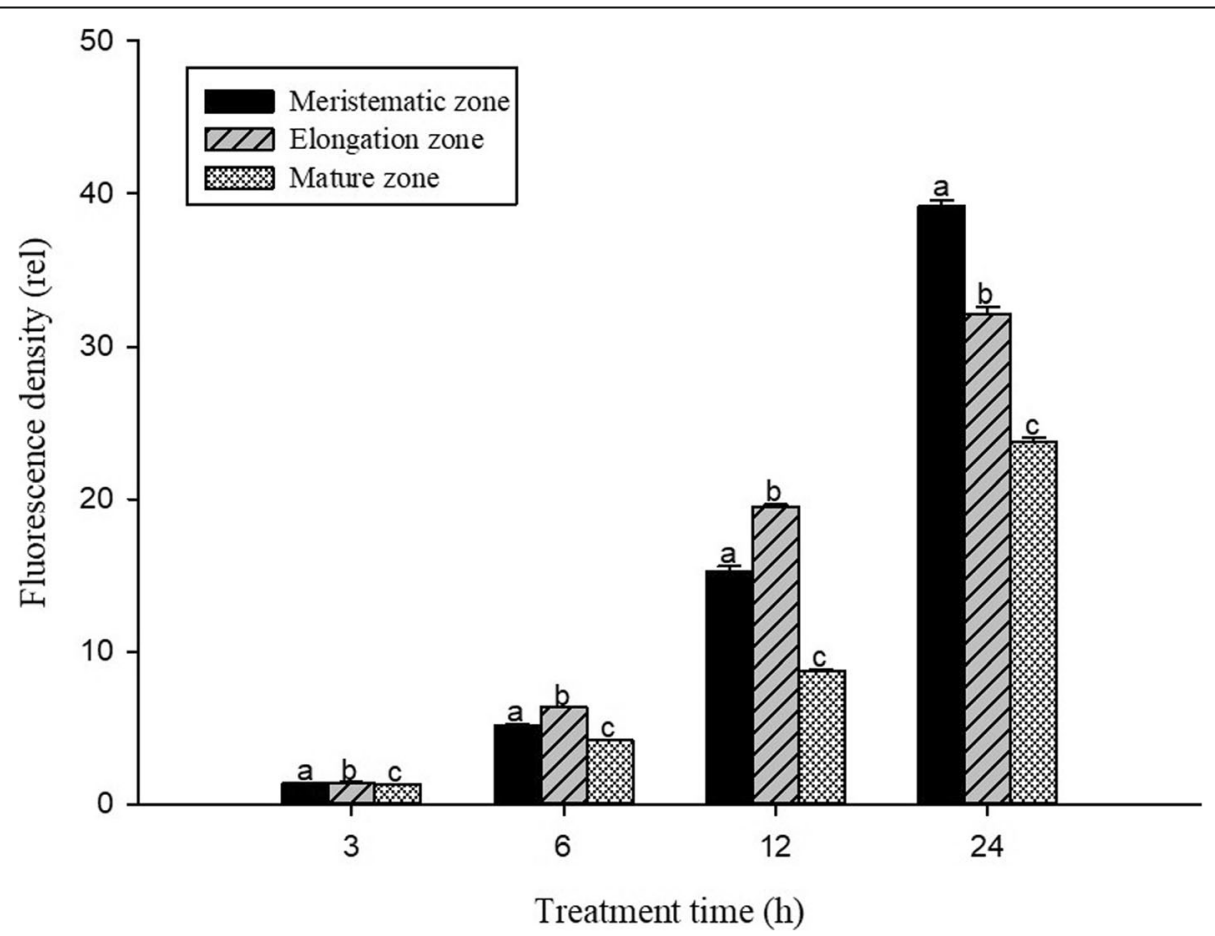

Fig. 9 Distribution of Leadamium ${ }^{\text {TM }}$ Green AM dye fluorescence density in the meristem, elongation, and mature zones at longitudinal sections of root tips treated with $100 \mu \mathrm{mol} / \mathrm{L} \mathrm{Pb}$ for $3,6,12$, and $24 \mathrm{~h}$ 

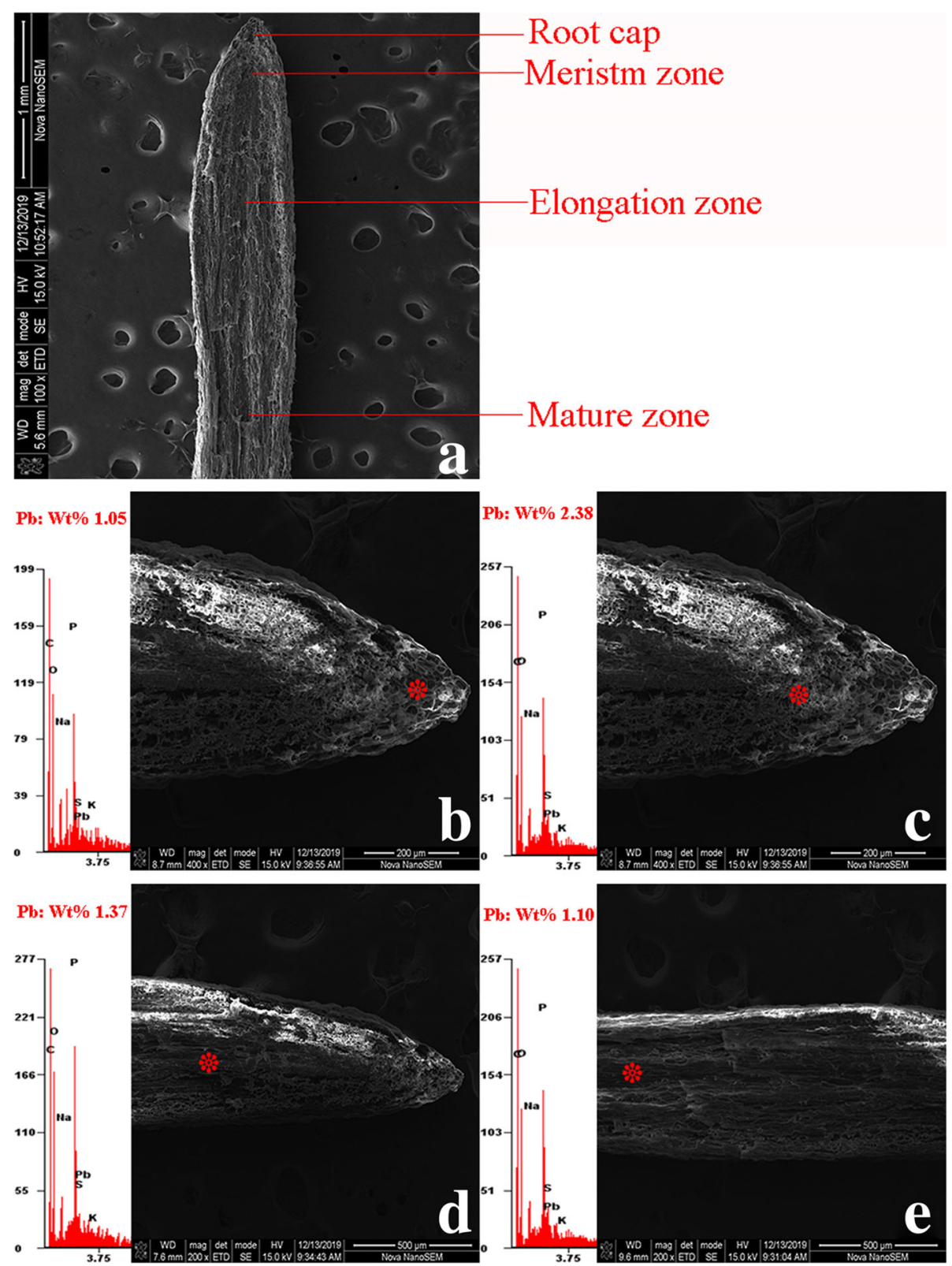

Fig. $10 \mathrm{SEM}$ micrographs and Pb localization in different zones of root tip cells exposed to $50 \mu \mathrm{mol} / \mathrm{L} \mathrm{Pb}$ for $24 \mathrm{~h}$. a: Intact root (scale bar $=1$ $\mathrm{mm})$, b: Root cap (scale bar $=200 \mu \mathrm{m})$, c: Meristem zone (scale bar $=200 \mu \mathrm{m})$, d: Elongation zone (scale bar $=500 \mu \mathrm{m})$, e: Mature zone $(\mathrm{scale}$ bar $=$ $500 \mu \mathrm{m}$ ). site of the analysis; $x$-axis energy [keV]

Therefore, understanding $\mathrm{Pb}$ uptake and accumulation in root sites, as well as evaluating the action mechanisms of $\mathrm{Pb}$ toxicity in plant root tip cells and their consequences on root growth and cell damage are very important. In this study, after a short exposure period, the results demonstrated that compared with the control $\mathrm{Pb}$ can restrain the growth of S. babylonica root, and the inhibition increased when $\mathrm{Pb}$ concentration increased, which is in accordance with the results reported by Jiang et al. [15], Khan et al. [18], Liu et al. [34], Wierzbicka [43], and Jiang and Liu [44]. However, further research is needed to assess the long-term ecological risks of $\mathrm{Pb}$ contamination under field conditions.

Fluorescent $\mathrm{Pb}$ reagents are rarely used in plant studies, however, Leadmium Green AM dye has been successfully used to detect $\mathrm{Pb}$ in plant roots [15]. The uptake of $\mathrm{Pb}$ in $S$. babylonica root cells was investigated using the Pb-sensitive Leadmium ${ }^{\mathrm{Tm}}$ Green AM dye in this study. Green fluorescence, which represents the binding of the dye to $\mathrm{Pb}$, was observed in the meristem zone of $S$. babylonica under $\mathrm{Pb}$ stress. An early study indicated that the meristem of plant roots is one of the most 

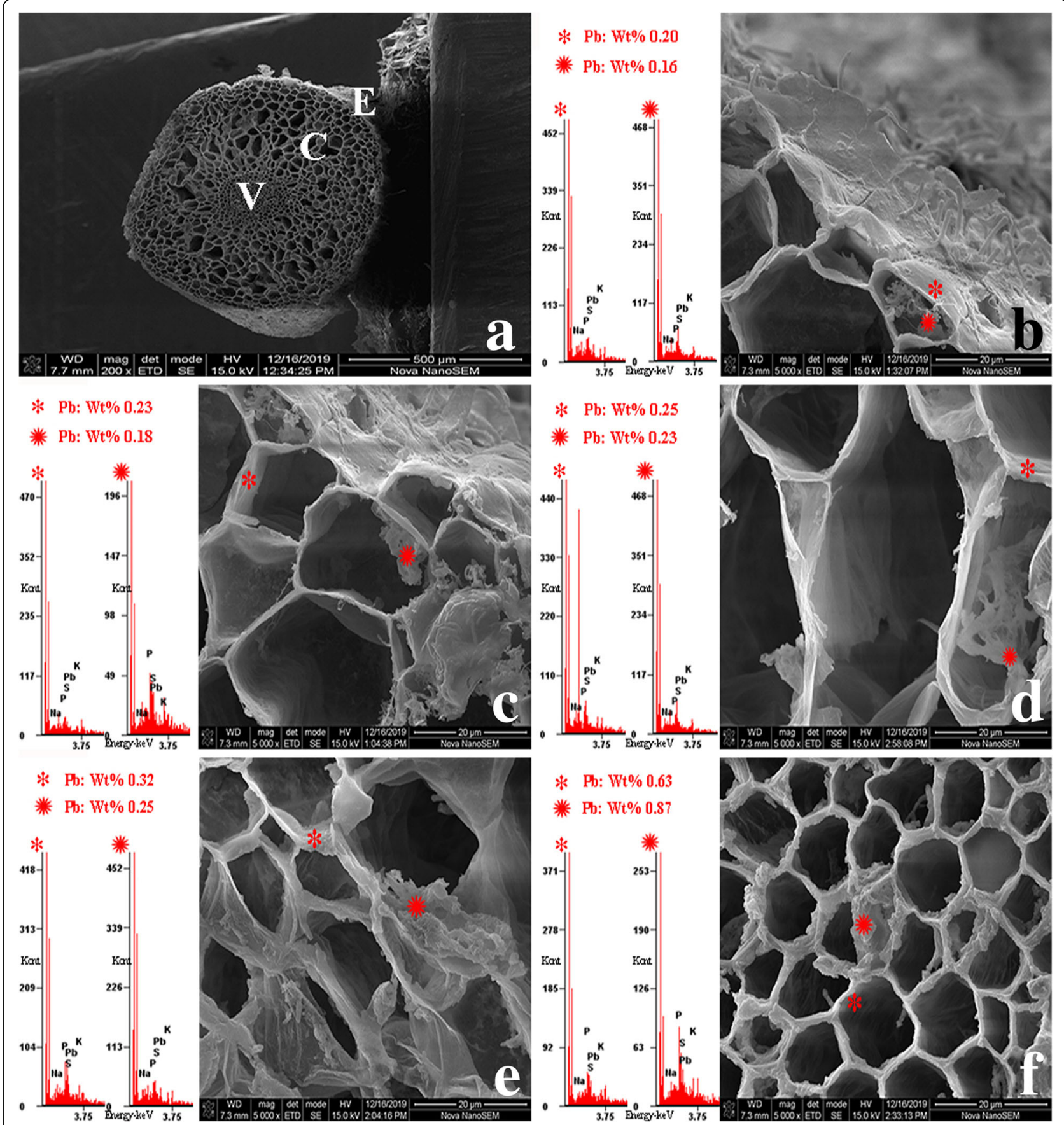

Fig. $11 \mathrm{SEM}$ micrographs and Pb localization at transverse sections in root mature zone cells exposed to $50 \mu \mathrm{mol} / \mathrm{L} \mathrm{Pb}$ for $24 \mathrm{~h}$. a: Transverse sections of the mature zone (scale bar $=500 \mu \mathrm{m}), \mathbf{b}$ : Epidermal cells (scale bar $=20 \mu \mathrm{m}), \mathbf{c}-\mathbf{e}$ : Cortical cells (scale bar $=20 \mu \mathrm{m})$, $\mathbf{f}$ : Vessel cells $(\mathrm{scale}$ bar $=20 \mu \mathrm{m}) .{ }^{*}$ cell wall, cytoplasm, E: epidermis, C: cortex, and V: vascular cylinder

sensitive sites to $\mathrm{Pb}$ toxicity [43]. The results of this study demonstrated that $\mathrm{Pb}$ ions were first accumulated in the elongation zone of root tips after exposure to $\mathrm{Pb}$ and were gradually transported to the meristem zone after prolonged exposure, suggesting that the meristem of plant root tips is a target of $\mathrm{Pb}$. In S. babylonica roots under $\mathrm{Pb}$ stress, the Leadmium Green AM data are very similar to the PI staining data, which demonstrates the existence of significant relevance between $\mathrm{Pb}$ accumulation and cell death in roots exposed to $\mathrm{Pb}$. The results here supported previous observations in which $\mathrm{Pb}$ was absorbed within hours in A. cepa root cells exposed to $\mathrm{Pb}[15,43]$. Rucińska-Sobkowiak et al. [45] demonstrated that accumulated $\mathrm{Pb}$ caused enlargements of the 

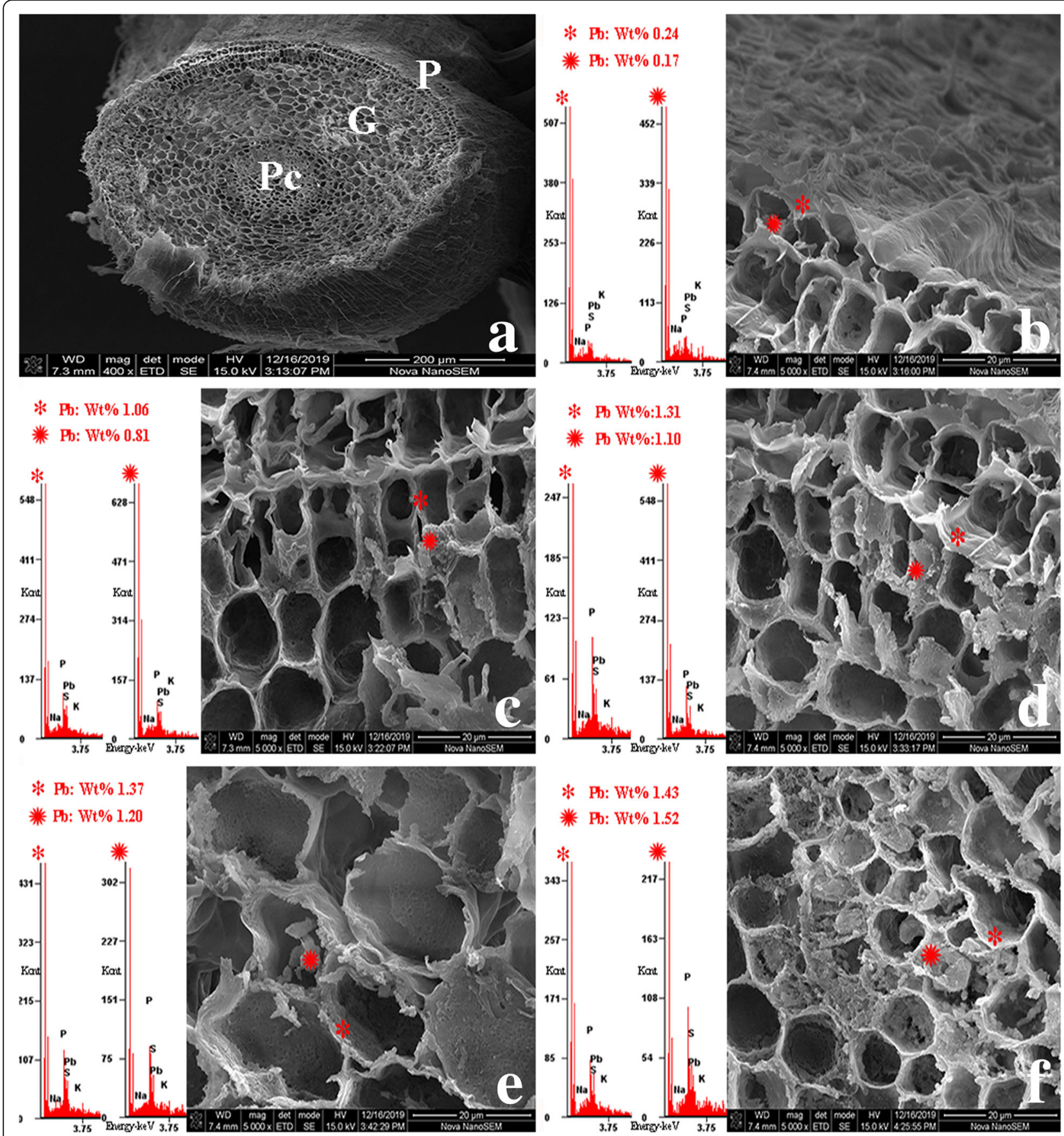

Fig. $12 \mathrm{SEM}$ micrographs and Pb localization at transverse sections in root meristem zone cells exposed to $50 \mu \mathrm{mol} / \mathrm{L} \mathrm{Pb}$ for $24 \mathrm{~h}$. a: Transverse section of meristem zone (scale bar $=200 \mu \mathrm{m})$, b: Protoderm (scale bar $=20 \mu \mathrm{m}), \mathbf{c}-\mathbf{e}$ : Ground meristem (scale bar $=20 \mu \mathrm{m})$, f: Procambium (scale bar $=20 \mu \mathrm{m}) .{ }^{*}$ cell wall, cytoplasm, P: protoderm, G: ground meristem, and Pc: procambium

apical meristems adjacent to root caps, leading to cell wall thickening and increased in the vacuole, which explained plant tolerance to $\mathrm{Pb}$ stress.

PI is an intercalating agent and fluorescent molecule used to stain DNA for studying cell membrane damage in plant roots after the exposure to heavy metals. The damage extent of cell membrane and morphological changes of cell membrane integrity can be reflected by the quantity of PI entered the cells [46-50]. In this study, the toxic effects of $\mathrm{Pb}$ on the cell membrane damaged S. babylonica root tip cells, which was confirmed by PI staining. The observed cell damage was mainly in the meristem and elongation zones of root tips exposed to $100 \mu \mathrm{mol} / \mathrm{L} \mathrm{Pb}$ for $3 \mathrm{~h}$ (Fig. 4). The PI staining data 
are in agreement with the $\mathrm{Pb}$ absorption observations in different zones of $S$. babylonica roots under $\mathrm{Pb}$ stress. Under heavy metal stress, reactive oxygen species (ROS) production also increased. ROS interact with various cellular components and lead to oxidative damage in nucleic acids, proteins, sugars, and lipids, which in turn cause oxidative stress to the intracellular membrane [50]. Under $\mathrm{Pb}$ stress, ROS-induced oxidative stress leads to lipid peroxidation in cell membranes, which in turn produce malondialdehyde (MDA) [17, 51]. Cell damage in the roots exposed to $\mathrm{Pb}$ may be explained by the fact that $\mathrm{Pb}$ causes the lipid peroxidation of membranes and oxidative damage, leading to permeability and fluidity changes of the membrane lipid bilayer and altering cell integrity. Consequently, ROS-induced cellular damage induces local programmed cell death, which generally affects plant growth and development.

EDXA is an analytical technique used for analyzing the localization of elements in biological specimens at the subcellular level $[48,52]$. In this study, EDXA at longitudinal sections showed that $\mathrm{Pb}$ ions accumulated in the meristem, elongation, and mature zones of S. babylonica root tips exposed to $\mathrm{Pb}$, and the accumulation and distribution of $\mathrm{Pb}$ exhibited the same trend as the fluorescent probe results. Additionally, the cell wall is considered the primary $\mathrm{Pb}$ accumulation sites then the cytoplasm. Cell wall is the first barrier for heavy metal to enter cells. Plant reduces the toxicity of $\mathrm{Pb}$ by binding it to the cell wall, which is one of the mechanisms of plant tolerance. At transverse sections, $\mathrm{Pb}$ levels in the meristem zone were high compared to the mature zone, supporting the findings of Eun et al. [53], which demonstrated that $\mathrm{Pb}$ accumulation occurred in both the apoplast and symplast, and that the $\mathrm{Pb}$ levels in the root meristem were the highest. Root hairs are located only in the root mature zone and increase the absorption surface area greatly, making the uptake of water and minerals more efficiently during osmosis. After $\mathrm{Pb}$ ions enter the roots, they penetrate cortical tissues and are translocated to aboveground tissues. This explains why the $\mathrm{Pb}$ levels in the mature zone are low compared to the meristem zone. Moreover, the results demonstrated that the $\mathrm{Pb}$ levels were ordered as follows: epidermal cells < cortical cells < vessel cells (Fig. 11b-f), which determined that $\mathrm{Pb}$ was easily translocated from roots to the aboveground part through vascular tissue. $\mathrm{The} \mathrm{Pb}$ levels in the meristem zone were higher compared to the mature zone, indicating that the $S$. babylonica root tip meristem is a target of $\mathrm{Pb}$ accumulation and toxicity. Meristem cells are small and have thin walls without differentiation. Because these cells have not yet differentiated, they have a poor transport capacity. Thus, excess $\mathrm{Pb}$ can easily damage cell construction, thereby inducing a low mitotic index and production of large damaged cells that inhibit $S$. babylonica seedlings.

\section{Conclusions}

Based on the results obtained in this investigation, we can draw the following conclusions. Under Pb stress, $\mathrm{Pb}$ ions initially entered elongation zone cells and gradually accumulated in the meristem zone, and they were localized primarily to the cell wall then to cytoplasm. $\mathrm{Pb}$ level in epidermal cells was the lowest compared to cortical and vessel cells, and there was an increasing trend in cortical cells from the epidermis to vascular cylinder. Cell damage in the roots exposed to $\mathrm{Pb}$ detected by $\mathrm{PI}$ staining was in agreement with the findings of $\mathrm{Pb}$ absorption in different zones of $S$. babylonica roots under $\mathrm{Pb}$ stress by SEM with EDXA. At $100 \mu \mathrm{mol} / \mathrm{L} \mathrm{Pb}$ treatment for $7 \mathrm{~d}$, the root $\mathrm{Pb}$ accumulation was $78.78 \pm$ $0.34 \mu \mathrm{g} / \mathrm{g}$ dry weight of the tissue, and the shoot $\mathrm{Pb}$ accumulation was $151.37 \pm 0.16 \mu \mathrm{g} / \mathrm{g}$ dry weight of the tissue. The TF value showed $>1$ in all treatment groups, although $\mathrm{Pb}$ exerted inhibitory effects on the root and shoot growth. Based on these characteristics, S. babylonica could be thought to have great potential for phytoextraction to $\mathrm{Pb}$ after the short-term investigation. The information obtained here would lead to a better understanding of $\mathrm{Pb}$ resistance and tolerance mechanisms, which would provide valuable and scientific information for phytoremediation investigations of other woody plants stressed by $\mathrm{Pb}$. However, further investigation on long-term $\mathrm{Pb}$ accumulation and distribution at even higher concentrations of $\mathrm{Pb}$ treatment is still required.

\section{Methods}

\section{Plant materials and growth conditions}

S. babylonica used in this experiment was identified and offered by Professor Wenhui Zhang of Northwest A\&F University, China. The collection of the experimental materials conforms to the institutional, national or international guidelines. Healthy woody cuttings ( $25 \mathrm{~cm}$ long) from 1-year-old S. babylonica shoots grown on the campus of Tianjin Normal University, China were collected and rooted in plastic buckets that contained distilled water. Seven-day-old woody cuttings with new roots were transferred to half-strength Hoagland nutrient solution containing $0,1,10,50$, or $100 \mu \mathrm{mol} / \mathrm{L} \mathrm{Pb}$ and grown for $7 \mathrm{~d}$. The nutrient solution consisted of $5 \mathrm{mM}$ $\mathrm{Ca}\left(\mathrm{NO}_{3}\right)_{2}, 5 \mathrm{mM} \mathrm{KNO} 3,1 \mathrm{mM} \mathrm{KH_{2 } \mathrm { PO } _ { 4 } , 1 \mathrm { mM } \mathrm { MgSO }}$, $50 \mu \mathrm{M} \mathrm{H}_{3} \mathrm{BO}_{3}, 10 \mu \mathrm{M}$ FeEDTA, $4.5 \mu \mathrm{M} \mathrm{MnCl}_{2}, 3.8 \mu \mathrm{M}$ $\mathrm{ZnSO}_{4}, 0.3 \mu \mathrm{M} \mathrm{CuSO}_{4}$, and $0.1 \mu \mathrm{M}\left(\mathrm{NH}_{4}\right)_{6} \mathrm{Mo}_{7} \mathrm{O}_{24}$ adjusted to $\mathrm{pH}$ 5.5. Control seedlings were grown in the nutrient solution alone. Solutions were continuously aerated with an aquarium air pump. Experiments were conducted in a greenhouse under a 14/10 h light/dark photoperiod at $26 / 18^{\circ} \mathrm{C}$ (day/night) and $65-75 \%$ humidity. The roots were protected from direct sunlight. $\mathrm{Pb}$ was supplied as lead nitrate $\left[\mathrm{Pb}\left(\mathrm{NO}_{3}\right)_{2}\right]$. All treatments 
were performed in triplicate. TF were calculated as follows [41]:

$$
\mathrm{TF}=\frac{\text { Metal concentration in shoot }}{\text { Metal concentration in root }}
$$

\section{Determination of $\mathrm{Pb}$}

Control and experimental plants stressed by $0,1,10,50$, or $100 \mu \mathrm{mol} / \mathrm{L} \mathrm{Pb}$ for $7 \mathrm{~d}$ were harvested randomly. In order to get rid of the traces of nutrients and $\mathrm{Pb}$ ions on their surfaces, the root samples were washed with running tap water for $30 \mathrm{~min}, 20 \mathrm{mM}$ disodium ethylenediamine tetraacetic acid $\left(\mathrm{Na}_{2}\right.$-EDTA) for $10 \mathrm{~min}$ and deionized water for $3 \mathrm{~min}$ in turn. Plant tissues were divided into roots and shoots (i.e., leaves, new stems, and old stems). Roots were dried at $45^{\circ} \mathrm{C}$ for $72 \mathrm{~h}, 80^{\circ} \mathrm{C}$ for $24 \mathrm{~h}$, and $105^{\circ} \mathrm{C}$ for $12 \mathrm{~h}$, then ground with a cutting mill (IKA-Werke GmbH \& CO. KG, Staufen, Germany). After weighing, dried-root material $(0.2 \mathrm{~g})$ was digested with a mixture of $\mathrm{HNO}_{3}$ and $\mathrm{HClO}_{4}(4: 1, \mathrm{v} / \mathrm{v})$ at $160^{\circ} \mathrm{C}$. Dried plant samples were prepared using the wetdigestion method [34]. After dry-ashing, $\mathrm{Pb}$ concentrations were analyzed using ICP-AES (Leeman Labs Inc., Hudson, NH, USA).

\section{PI staining}

S. babylonica root tips exposed to different $\mathrm{Pb}$ concentrations $(0,1,10,50$, or $100 \mu \mathrm{mol} / \mathrm{L})$ for $3,6,12$, and 24 $\mathrm{h}$ were washed three times with phosphate-buffered saline (PBS, pH 7.0). Samples were soaked in $1 \mathrm{mmol} / \mathrm{L}$ PI (Sigma-Aldrich, Buchs, Switzerland) at $25^{\circ} \mathrm{C}$ for $8 \mathrm{~min}$ in the dark, and then thoroughly washed with phosphate buffer ( $50 \mathrm{mmol} / \mathrm{L}, \mathrm{pH} 7.8$ ). According to the methods of Zou et al. [54], Eclipse 90i laser confocal scanning microscope (Nikon Corp., Tokyo, Japan) was adopted to examine the samples, with the excitation maximum set at $535 \mathrm{~nm}$ and that of fluorescence emission at $617 \mathrm{~nm}$. Due to the extremely low penetrability across intact membranes, red fluorescence triggered by PI can only be observed in the nuclei of damaged cells. Red fluorescence is an indicator of cell damage [50, 54]. Fluorescence density was analyzed using the "Analyze and Measure" function in Image J software (NIH, Bethesda, MD, USA).

\section{Fluorescence labelling of $\mathrm{Pb}$}

$S$. babylonica root tips exposed to different $\mathrm{Pb}$ concentrations $(0,1,10,50$, or $100 \mu \mathrm{mol} / \mathrm{L})$ for $3,6,12$, and 24 $\mathrm{h}$ were soaked in EDTA solution $\left(\mathrm{Na}_{2}\right.$-EDTA, $20 \mathrm{mmol} /$ $\mathrm{L}$ ) and washed with running water for $15 \mathrm{~min}$. Then, root tips were washed with deionized water 3 times. Afterwards, experimental and control roots were stained using the $\mathrm{Pb}$-specific probe Leadmium $^{\text {Tix }}$ Green AM solution (Molecular Probes, Invitrogen, Carlsbad, CA, USA) for $90 \mathrm{~min}$ at $40{ }^{\circ} \mathrm{C}$ in the dark following the manufacturer's instructions to visualize $\mathrm{Pb}$ absorption and distribution [55]. Intact cells exhibited green fluorescence due to the $\mathrm{Pb}$-specific probe Leadmium ${ }^{\mathrm{Tm}}$ Green AM solution. Fluorescence density was analyzed using the "Analyze and Measure" function in Image J software to evaluate the $\mathrm{Pb}$ distribution in intact roots. Prepared samples were observed using a Nikon Eclipse 90i confocal laser scanning microscope with an exciter at 488 $\mathrm{nm}$ and a barrier at 590/50 $\mathrm{nm}$.

\section{Sample preparation for SEM and EDXA}

The elemental distribution and composition of experimental plants were determined from freeze-dried root materials. S. babylonica roots treated with $50 \mu \mathrm{mol} / \mathrm{L} \mathrm{Pb}$ for $24 \mathrm{~h}$ were removed from the $\mathrm{Pb}\left(\mathrm{NO}_{3}\right)_{2}$ solution and washed thoroughly. Samples $(1 \mathrm{~cm}$ long) were cut from the root tips, soaked in $20 \mathrm{mM}$ EDTA- $\mathrm{NO}_{2}$ solution for $15 \mathrm{~min}$, and washed three times with $\mathrm{dd}_{2} \mathrm{O}$ for $10 \mathrm{~min}$. Materials were washed three times with PBS ( $\mathrm{pH}$ 7.2) for $10 \mathrm{~min}$. According to the methods referred by Shi et al. [52], the root tips were frozen quickly in liquid nitrogen and lyophilized in vacuum. An Emitech K550X sputter/ coater (Quorum Group, London, England) was adopted to gild the root samples. A FEI Nova NanoSEM 230 (FEI Company, Oregon, USA) with a Genesis Apollo 10 EDXA (FEI Company, Oregon, USA) was employed to carry out EDXA. Via an X-ray and X-ray detector with a super ultra-thin window, the spectra were collected at $20 \mathrm{kV}$ for $30-40 \mathrm{~s}$. Pb contents were calculated as weight percent (Wt\%) (i.e., the weight-based (or mass) percent concentration of a certain element relative to the gross element weight (or mass)).

\section{Statistical analyses}

Fifteen seedlings were involved in each treatment, which was repeated five times to achieve statistical validity. SPSS v17.0 (SPSS Inc., Illinois, USA) and SigmaPlot v8.0 (Systat Software Inc., San Jose, CA) were adopted to analyze the results. The data are expressed as the mean \pm standard error (SE). A one-way analysis of variance (ANOVA) was applied to determine the differences between treatments. In the case of $p<0.05$, the results were deemed as statistically significant.

\footnotetext{
Abbreviations

Pb: Lead; ICP-AES: Inductively coupled plasma atomic emission spectrometry; TF: Translocation factor; BCF: Bio-concentration factor; PI: Propidium iodide; SEM: Scanning electron microscopy; EDXA: Energy-dispersive X-ray analyses; ROS: Reactive oxygen species; MDA: Malondialdehyde; PBS: Phosphate buffer saline; SE: Standard error; ANOVA: Analysis of variance
}

\section{Acknowledgments}

We thank LetPub (www.letpub.com) for its linguistic assistance during the preparation of this manuscript. 


\section{Authors' contributions}

WX participated in plant cultivation, experimental operation and collecting the materials. YJ participated in the data analysis and helped draft the manuscript. XS carried out materials collecting. JZ designed the study and drafted the manuscript. All authors have read and approved this manuscript.

\section{Funding}

This project was supported by Natural Science Foundation of China (grant No. 31901184) and Doctor Foundation of Tianjin Normal University (grant No. 52XB1914). The funding body supported the study, analysis of data and writing the manuscript.

\section{Availability of data and materials}

The datasets used and/or analysed during the current study are available from the corresponding author on reasonable request.

\section{Ethics approval and consent to participate}

Not applicable.

\section{Consent for publication}

Not applicable.

\section{Competing interests}

The authors declare that they have no competing interests.

Received: 28 January 2020 Accepted: 16 June 2020

Published online: 29 June 2020

\section{References}

1. Obiora SC, Chukwu A, Toteu SF, Davies TC. Assessment of heavy meta contamination in soils around lead (Pb)-zinc ( $\mathrm{Zn}$ ) mining areas in Enyigba, southeastern Nigeria. J Geol Soc. 2016;87(4):453-62.

2. Kumar A, Kumar A, Cabral-Pinto MMS, Chaturvedi AK, Shabnam AA, Subrahmanyam G, Mondal R, Gupta DK, Malyan SK, S Kumar S, A Khan S, Yadav KK. Lead toxicity: Health hazards, influence on food chain, and sustainable remediation approaches. Int J Env Res Pub He. 2020:17(7):2179.

3. Khan I, Iqbal M, Shafiq F. Phytomanagement of lead-contaminated soils: critical review of new trends and future prospects. Int J Environ Sci Te. 2019; 16(10):6473-88.

4. Zulfiqar U, Faroog M, Hussain S, Maqsood M, Hussain M, Ishfaq M, Ahmad M, Anjum MZ. Lead toxicity in plants: Impacts and remediation. J Environ Manag. 2019;250:UNSP 109557.

5. Leal-Alvarado DA, Espadas-Gil F, Saenz-Carbonell L, Talavera-May C, Santamaria JM. Lead accumulation reduces photosynthesis in the lead hyper-accumulator Salvinia minima baker by affecting the cell membrane and inducing stomatal closure. Aquat Toxicol. 2016;171:37-47.

6. Jiang Z, Zhang HN, Qin R, Zou JH, Wang JR, Shi QY, Jiang WS, Liu DH. Effects of lead on the morphology and structure of the nucleolus in the root tip meristematic cells of Allium cepa L. Int J Mol Sci. 2014;15(8):13406-23.

7. Ding GH, Li CY, Han X, Chi CY, Zhang DW, Liu BD. Effects of lead on ultrastructure of Isoetes sinensis palmer (Isoetaceae), a critically endangered species in China. PLoS One. 2015;10(9):e0139231.

8. Ferreyroa GV, Lagorio MG, Trinelli MA, Lavado RS, Molina FV. Lead effects on Brassica napus photosynthetic organs. Ecotox Environ Safe. 2017;140:123-30.

9. Kumar A, Prasad MNV, Sytar O. Lead toxicity, defense strategies and associated indicative biomarkers in Talinum triangulare grown hydroponically. Chemosphere. 2012;89(9):1056-65.

10. Saleem M, Asghar HN, Zahir ZA, Shahid M. Impact of lead tolerant plant growth promoting rhizobacteria on growth, physiology, antioxidant activities, yield and lead content in sunflower in lead contaminated soil. Chemosphere. 2018;195:606-14.

11. Chandrasekhar C, Ray JG. Copper accumulation, localization and antioxidant response in Eclipta alba L. in relation to quantitative variation of the metal in soil. Acta Physiol Plant. 2017;39(9):205

12. Wang J, Ye S, Xue SG, Hartley W, Wu H, Shi LZ. The physiological response of Mirabilis jalapa Linn. To lead stress and accumulation. Int Biodeterior Biodegradation. 2018:128:11-4.

13. Liu DH, Jiang WS, Liu CJ, Xin CH, Hou WQ. Uptake and accumulation of lead by roots, hypocotyls and shoots of Indian mustard (Brassica juncea L.) Bioresource Tech. 2000;71(3):273-7.
14. Kiran BR, Prasad MNV. Responses of Ricinus communis L. (castor bean, phytoremediation crop) seedlings to lead (Pb) toxicity in hydroponics. Selcuk J Agri Food Sci. 2017;31(1):73-80.

15. Jiang Z, Qin R, Zhang HH, Zou JH, Shi QY, Wang JR, Jiang WS, Liu DH. Determination of $\mathrm{Pb}$ genotoxic effects in Allium cepa root cells by fluorescent probe, microtubular immunofluorescence and comet assay. Plant Soil. 2014;383(1-2):357-72.

16. Liu XJ, Shi QY, Zou JH, Wang JR, Wu HF, Wang JY, Jiang WS, Liu DH. Chromosome and nucleolus morphological characteristics in root tip cells of plants under metal stress. Fresenius Environ Bull. 2016;25(7):2419-26.

17. Hattab S, Hattab S, Flores-Casseres ML, Boussetta H, Doumas P, Hernandez LE, Banni M. Characterisation of lead-induced stress molecular biomarkers in Medicago sativa plants. Environ Exp Bot. 2016;123:1-12.

18. Khan MM, Islam E, Irem S, Akhtar K, Ashraf MY, Iqbal J, Liu D. Pb induced phytotoxicity in para grass (Brachiaria mutica) and castor bean (Ricinus communis I.): Antioxidant and ultrastructural studies. Chemosphere. 2018; 200:257-65.

19. Kumar A, Prasad MNV. Plant-lead interactions: transport, toxicity, tolerance, and detoxification mechanisms. Ecotox Environ Safe. 2018;166:401-18.

20. El-Banna MF, Mosa A, Gao B, Yin XQ, Wang HY, Ahmad Z. Scavenging effect of oxidized biochar against the phytotoxicity of lead ions on hydroponically grown chicory: an anatomical and ultrastructural investigation. Ecotox Environ Safe. 2019;170:363-74

21. Sha S, Cheng MH, Hu KJ, Zhang W, Yang YR, Xu QS. Toxic effects of Pb on Spirodela polyrhiza (L.): subcellular distribution, chemical forms, morphological and physiological disorders. Ecotox Environ Safe. 2019;181:146-54.

22. Zou JH, Wang G, Ji J, Wang JY, Wu HF, Ouyang YJ, Li BB. Transcriptional, physiological and cytological analysis validated the roles of some key genes linked cd stress in Salix matsudana Koidz. Environ Exp Bot. 2017:134:116-29.

23. Ouyang J, Li BB, Li CH, Shang XS, Zou JH. Cadmium effects on mineral accumulation and selected physiological and biochemical characters of Salix babylonica L. Pol J Environ Stud. 2017;26(6):2667-76.

24. Zhivotovsky OP, Kuzovkina JA, Schulthess CP, Morris T, Pettinelli D, Ge M. Hydroponic screening of willows (Salix L.) for lead tolerance and accumulation. Int J Phytoremediat. 2011;13(1):75-94.

25. Zhivotovsky OP, Kuzovkina YA, Schulthess CP, Morris T, Pettinelli D. Lead uptake and translocation by willows in pot and field experiments. Int J Phytoremediat. 2011;13(8):731-49.

26. Kersten G, Majestic B, Quigley M. Phytoremediation of cadmium and leadpolluted watersheds. Ecotox Environ Safe. 2017;137:225-32.

27. Zhao FL, Yang WD. Review on application of willows (Salix spp.) in remediation of contaminated environment. Acta Agriculturae Zhejiangensis. 2017:29(2):300-6.

28. Li H, Zhang GC, Xie HC, Li K, Zhang SY. The effects of the phenol concentrations on photosynthetic parameters of Salix babylonica $\mathrm{L}$. Photosynthetica. 2015:53(3):430-5.

29. Wang QB, Chen GC, Fang J, Lou C, Zhang JF. Characteristics of soil lead tolerance, accumulation and distribution in Salix babylonica Linn. And Salix jiangsuensis J172. Bulletin Botanical Res. 2014;34(5):626-33.

30. Salazar MJ, Pignata ML. Lead accumulation in plants grown in polluted soils. Screening of native species for phytoremediation. J Geochem Explor. 2014; 137:29-36.

31. Bernardino CAR, Mahler CF, Preussler KH, Novo LAB. State of the art of phytoremediation in Brazil-review and perspectives. Water Air Soil Pollut. 2016;227(8):272.

32. Koptsik GN. Problems and prospects concerning the phytoremediation of heavy metal polluted soils: a review. Eurasian Soil Sci. 2014;47(9):923-39.

33. Buscaroli A. An overview of indexes to evaluate terrestrial plants for phytoremediation purposes (review). Ecol Indic. 2017;82:367-80.

34. Liu DH, Zou J, Meng QM, Zou JH, Jiang WS. Uptake and accumulation and oxidative stress in garlic (Allium sativum L.) under lead phytotoxicity. Ecotoxicology. 2009;18(1):134-43.

35. Zhou CF, Huang MY, Li Y, Luo JW, Cai LP. Changes in subcellular distribution and antioxidant compounds involved in Pb accumulation and detoxification in Neyraudia reynaudiana. Environ Sci Pollut R. 2016;23(21): 21794-804

36. Wu HF, Wang JY, Li BB, Ouyang J, Wang JR, Shi QY, Jiang WS, Liu DH, Zou $J$ H. Salix matsudana Koidz tolerance mechanisms to cadmium: uptake and accumulation, subcellular distribution, and chemical forms. Pol J Environ Stud. 2016;25(4):1739-47. 
37. Courchesne F, Turmel MC, Cloutier-Hurteau B, Constantineau S, Munro L, Labrecque M. Phytoextraction of soil trace elements by willow during a phytoremediation trial in southern Quebec. Canada Int J Phytoremediat. 2017;19(6):545-54.

38. Ouyang J, Li BB, Xue WX, Jiang Y, Li CH, Shang XS, Zou JH. Cadmium uptake and accumulation, subcellular distribution and chemical forms in young seedlings of Salix babylonica L. Fresenius Environ Bull. 2019;28(5): 3637-48.

39. Zou JH, Shang XS, Li CH, Ouyang J, Li BB, Liu XJ. Effects of cadmium on mineral metabolism and antioxidant enzyme activities in Salix matsudana Koidz. Pol J Environ Stud. 2019;28(2):989-99.

40. Shang XS, Xue WX, Jiang Y. Effects of calcium on the alleviation of cadmium toxicity in salix matsudana and its effects on other minerals. Pol J Environ Stud. 2020;29(2):2001-10.

41. Chandrasekhar C, Ray JG. Lead accumulation, growth responses and biochemical changes of three plant species exposed to soil amended with different concentrations of lead nitrate. Ecotox Environ Safe. 2019;171:26-36.

42. Wang WW, Cheng LK, Hao JW, Guan X, Tian XJ. Phytoextraction of initial cutting of Salix matsudana for Cd and Cu. Int J Phytoremediation. 2019; 21(2):84-91.

43. Wierzbicka M. Resumption of mitotic activity in Allium cepa L. root tips during treatment with lead salts. Environ Exp Bot. 1994;34(2):173-80.

44. Jiang WS, Liu DH. Effects of $\mathrm{Pb}^{2+}$ on root growth, cell division and nucleolus of Brassica juncea L. Isr J Plant Sci. 1999:47(3):153-6.

45. Rucińska-Sobkowiak R, Nowaczyk G, Krzesłowska M, Rabęda I, Jurga S. Water status and water diffusion transport in lupine roots exposed to lead. Environ Exp Bot. 2013;87:100-9

46. Liao TT, Shi YL, Jia JW, Wang L. Sensitivity of different cytotoxic responses of vero cells exposed to organic chemical pollutants and their reliability in the bio-toxicity test of trace chemical pollutants. Biomed Environ Sci. 2010;23(3): 219-29.

47. Liao TT, Jia RW, Shi YL, Jia JW, Wang L, Chua H. Propidium iodide staining method for testing the cytotoxicity of 2,4,6-trichlorophenol and perfluorooctane sulfonate at low concentrations with vero cells. J Environ Sci Heal A. 2011;46(14):1769-75.

48. Wang JR, Shi QY, Zou JH, Jiang Z, Wang JY, Wu HF, Jiang WS, Liu DH. Cellular localization of copper and its toxicity on root tips of Hordeum vulgare. Fresenius Environ Bull. 2015;24(7):2394-405.

49. Shi QY, Wang JR, Zou JH, Jiang Z, Wu HF, Wang JY, Jiang WS, Liu DH. Cadmium localization and its toxic effects on root tips of barley. Zemdirbyste. 2016;103(2):151-8.

50. Wu HF, Wang JY, Ouyang J, Li BB, Jiang WS, Liu DH, Zou JH. Characterisation of early responses to cadmium in roots of Salix matsudana Koidz. Environ Toxicol Chem. 2017:99(5-6):913-25.

51. Ashraf U, Tang XR. Yield and quality responses, plant metabolism and metal distribution pattern in aromatic rice under lead ( $\mathrm{Pb}$ ) toxicity. Chemosphere. 2017; 176:141-55

52. Shi QY, Wang JR, Zou JH, Jiang Z, Wang JY, Wu HF, Jiang WS, Liu DH. Cd subcellular localization in root tips of Hordeum vulgare. Pol J Environ Stud. 2016;25(2):903-8.

53. Eun SO, Youn HS, Lee Y. Lead disturbs miceotubule organization in root meristem of Zea mays. Physiol Plant. 2000;110:357-65.

54. Zou JH, Wang G, Ji J, Wang JY, Ouyang J, Lie BB. Cadmium' s effect on the organization of microtubular cytoskeleton in root tips cells of Salix matsudana Koidz. Pol J Environ Stud. 2018;27(2):939-46.

55. Piper CS. Soil and plant analysis. Australia: Monograph, Waite Agric Res Inst. The University of Adelaide; 1942.

\section{Publisher's Note}

Springer Nature remains neutral with regard to jurisdictional claims in published maps and institutional affiliations.

\section{Ready to submit your research? Choose BMC and benefit from:}

- fast, convenient online submission

- thorough peer review by experienced researchers in your field

- rapid publication on acceptance

- support for research data, including large and complex data types

- gold Open Access which fosters wider collaboration and increased citations

- maximum visibility for your research: over $100 \mathrm{M}$ website views per year

At $\mathrm{BMC}$, research is always in progress.

Learn more biomedcentral.com/submissions 